\title{
National and Regional Identities in Central and East Europe after 1989: A Review of Books by Donskis, Foster and Wigmore, and Koczanowicz and Singer
}

\author{
Agata Anna Lisiak \\ University of Halle-Wittenberg
}

Follow this and additional works at: https://docs.lib.purdue.edu/clcweb

C.

Part of the Comparative Literature Commons, and the Critical and Cultural Studies Commons

Dedicated to the dissemination of scholarly and professional information, Purdue University Press selects, develops, and distributes quality resources in several key subject areas for which its parent university is famous, including business, technology, health, veterinary medicine, and other selected disciplines in the humanities and sciences.

CLCWeb: Comparative Literature and Culture, the peer-reviewed, full-text, and open-access learned journal in the humanities and social sciences, publishes new scholarship following tenets of the discipline of comparative literature and the field of cultural studies designated as "comparative cultural studies." Publications in the journal are indexed in the Annual Bibliography of English Language and Literature (Chadwyck-Healey), the Arts and Humanities Citation Index (Thomson Reuters ISI), the Humanities Index (Wilson), Humanities International Complete (EBSCO), the International Bibliography of the Modern Language Association of America, and Scopus (Elsevier). The journal is affiliated with the Purdue University Press monograph series of Books in Comparative Cultural Studies. Contact: <clcweb@purdue.edu>

\section{Recommended Citation}

Lisiak, Agata Anna "National and Regional Identities in Central and East Europe after 1989: A Review of Books by Donskis, Foster and Wigmore, and Koczanowicz and Singer." CLCWeb: Comparative Literature and Culture 9.4 (2007): <https://doi.org/10.7771/1481-4374.1303>

This text has been double-blind peer reviewed by $2+1$ experts in the field.

The above text, published by Purdue University Press @Purdue University, has been downloaded 526 times as of $11 /$ $07 / 19$.

This document has been made available through Purdue e-Pubs, a service of the Purdue University Libraries. Please contact epubs@purdue.edu for additional information.

This is an Open Access journal. This means that it uses a funding model that does not charge readers or their institutions for access. Readers may freely read, download, copy, distribute, print, search, or link to the full texts of articles. This journal is covered under the CC BY-NC-ND license. 


\section{PURDUE}

UNIVERSITY PRESS <http://www.thepress.purdue.edu>

\section{CLCWeb: Comparative Literature and Culture}

ISSN 1481-4374 <http://docs.lib.purdue.edu/clcweb> Purdue University Press (CPurdue University

CLCWeb: Comparative Literature and Culture, the peer-reviewed, full-text, and open-access learned journal in the humanities and social sciences, publishes new scholarship following tenets of the discipline of comparative literature and the field of cultural studies designated as "comparative cultural studies." In addition to the publication of articles, the journal publishes review articles of scholarly books and publishes research material in its Library Series. Publications in the journal are indexed in the Annual Bibliography of English Language and Literature (Chadwyck-Healey), the Arts and Humanities Citation Index (Thomson Reuters ISI), the Humanities Index (Wilson), Humanities International Complete (EBSCO), the International Bibliography of the Modern Langua-ge Association of America, and Scopus (Elsevier). The journal is affiliated with the Purdue University

Press monog-raph series of Books in Comparative Cultural Studies. Contact: <clcweb@purdue.edu>

CLCWeb Volume 9 Issue 4 (December 2007) Book Review Article

Agata A. Lisiak, "National and Regional Identities in Central and East Europe after 1989:

A Review of Books by Donskis, Foster and Wigmore, and Koczanowicz and Singer" <http://docs.lib.purdue.edu/clcweb/vol9/iss4/6>

Contents of CLCWeb: Comparative Literature and Culture 9.4 (2007)

<http://docs.lib.purdue.edu/clcweb/vol9/iss4/> 
Agata A. Lisiak

"Review of Books by Donskis, Foster and Wigmore, and Koczanowicz and Singer"

\section{Agata A. LISIAK}

\section{National and Regional Identities in Central and East Europe after 1989:} A Review of Books by Donskis, Foster and Wigmore, and Koczanowicz and Singer

The twentieth century in Europe is commonly considered to have been an age of nation states. Some of them were formed in the nineteenth century as a result of unification of culturally related, but hitherto politically independent countries (e.g., Italy, Germany); others emerged from the Versailles Treaty after centuries of political dependence or nonexistence (e.g., Poland, Czechoslovakia, Yugoslavia). Young and inexperienced, the newly established states were often prone to populist ideologies. Nationalist movements spread through Europe like a medieval plague and reached even such historically mature countries as Spain and Portugal. Ideally, a nation state would be a state inhabited by a single nation. In Europe, however, political borders did not (and still do not) match the national ones and each country contains ethnic and religious minorities. Therefore, the idea of a European nation state was and remains socially unrealistic; the attempts to implement it led to ethnic cleansings and brought about the most traumatic experience of the twentieth century: the Holocaust. After World War II, nation states continued to be influential actors in world politics, but differences between them were less important than the Cold War division, especially in Central and East Europe, caught in the iron embrace of Soviet ideologies. Although Moscow played with national(ist) sentiments skillfully in its satellite countries and allowed for patriotic outbursts once in a while, the "world proletariat" kept its primary position in hierarchy and after the demise of the Soviet empire in 1989 Central and East European countries were confronted with a necessity of redefining their national identities and shaping anew their states.

The end of the Cold War division coincided with -- and, to a certain extent, contributed to -new ways of perceiving states and regions. Within the European Union (EU) regions were granted more power and independence from the state capital. Structural and cohesion funds were aimed at the development of regions rather than member states. Transnational regional initiatives increased cooperation beyond borders and led to the strengthening of local loyalties. In some cases, the regions hitherto suppressed by the state (e.g., the Basque country) were given more independence owing to the EU regional policy. Another remarkable reason for the shift of attention from the state to the region was that in the late twentieth century -- due to the collapse of the Cold War, among other factors -- the world became increasingly globalized. According to Zygmunt Bauman, "ethnic and tribal loyalties" flourish in a globalized world: "As the community loses its hold on the faith and the daily life of its members, and as communal identity and territorial sovereignty lose their practical import, all three gain in spiritual significance" (ix). If regional loyalties are as crucial in shaping identity as Bauman claims, we may wonder how these developments influence national loyalties, especially in the countries that only recently regained their independence. Furthermore, how do political and economic transformations influence the process of (re)inventing national and regional identities? Ever since 1989 Central and East Europe has been experiencing outbursts of nationalism, ethnic conflicts, and the growing popularity of populist parties, which invites analogies with the interwar period. Is it reasonable or too far-fetched to compare the current situation in Central and East Europe to the political and social chaos that reigned after the collapse of the Austro-Hungarian Empire? Three recent publications from Rodopi attempt to answer these and other questions.

Democracy and the Post-Totalitarian Experience edited by Leszek Koczanowicz and Beth J. Singer (2005) and Neighbours and Strangers: Literary and Cultural Relations in Germany, Austria and Central Europe since 1989 edited by Ian Foster and Juliet Wigmore (2004) are collections of conference papers and, thus, give witness to the importance of above questions in contemporary academic discourse. The third book discussed in this paper is a single-author study of Lithuanian philosophy, Leonidas Donskis's Loyalty, Dissent, and Betrayal: Modern Lithuania and East-Central European Moral Imagination (2005). Although these publications focus on different countries as well as different areas of knowledge (philosophy, literature, politics, etc.), they all discuss -- directly and indirectly -- aspects of shaping national and regional identities in Central and East Eu- 
Agata A. Lisiak,

"Review of Books by Donskis, Foster and Wigmore, and Koczanowicz and Singer"

rope after 1989. To begin with Donskis's Loyalty, Dissent, and Betrayal, he announces in the introduction that his book "reveals what it means to live in a changing society" (9). Ambitious as the statement appears, it is not the complexity of the task that prevents Donskis from accomplishing his aim: the author preoccupies himself with philosophical, cultural, and political theories rather than with a society exposed to transformations. Perhaps the mistake lies simply in the inaccurate phrasing of the goal of the book, which has very little to do with its contents. Donskis only briefly sketches the social situation in Lithuania after the country proclaimed its independence in 1990. The most interesting observation he makes here is the description of drastic changes in the perception of the West. The author reminds us that Soviet propaganda used to disclose Western economies as ruthlessly capitalist; however, the young and wild capitalism that ruled over the former Soviet republics in the 1990s was much more brutal and barbarous than British or German economic systems that suddenly appeared gentle and humane (3). Donskis does not hide his contempt for the new economic and social developments: "Lithuania seems locked mentally somewhere between the discovery of the intrinsic logic of capitalism characteristic of the nineteenth century and post-Weimar Republic period -- incredibly fast economic growth and passionate advocacy of the values of free enterprise and capitalism, accompanied by a good deal of anomie, fission of the body social, stark social contrasts, a shocking degree of corruption, a culture of poverty ... and cynicism" (4). The parallel between Lithuania and post-1933 Germany is exaggerated, but the point the author makes remains nonetheless alarming. Donskis looks for solutions among intellectuals and artists who are "ahead of many social and political processes that are on their way to Lithuania" (5). What he forgets to add here is how it happened that these intellectuals are so much ahead of the rest of the society: they learned their lessons in the West. It is at this point that the real aim of Donskis's book surfaces: a praise of great Lithuanian emigré thinkers.

The first chapter guides us through Lithuanian philosophy in the twentieth century: Donskis briefly discusses schools, inspirations, influences, the changing role of philosophy (and philosophers) in public life, and ends with a comparison between the emigré philosophers and those who stayed in Lithuania after its annexation by the Soviet Union in 1945. It is clear and logical that, as a liberal thinker, Donskis sympathizes with the more enlightened emigrés rather than those who were forced or chose to conform to Soviet ideologies. Still, the author does not praise all émigré thinkers, but only those who promote and develop ideas of liberal nationalism -- "a crucial framework for the modernizing critique of society and culture" (33). From this point on, Donskis's book represents an evaluation of the works and lives of three Lithuanian émigré intellectuals who propagate liberal nationalism: Vytautas Kavolis, Aleksandras Shtromas, and Tomas Venclova. To Donskis, "they are all a perfect embodiment of what has been termed by Tomas Venclova the second voice of culture, the voice which acquires crucial significance when the first voice either remains silent or sings the wrong and imposed melody" (33). Fascinating as it is to look at these emigré scholars' perception of their home country as well as their views on national identity and mentality, national fears and hopes, it would undoubtedly help create a bigger picture if Donskis chose to juxtapose -- at length rather than only in passing -- the stance of liberal nationalists with positions of other Lithuanian theoreticians of the nation. Donskis evaluates through the prism of his own work Lithuanian philosophy altogether: "A good part of Lithuanian philosophy still remains surprisingly self-contained, self-centered, and inattentive to major intellectual challenges of the second half of the twentieth century" (28). Consequently, there is hardly any literature on Lithuanian philosophy (or even Lithuanian philosophical literature) available in major European languages. Thus, an important aspect of Donskis's English-language book is that it creates a chance for retrieving Lithuanian philosophy from neglect. The question is, however, whether the author directs the reader's attention at the largely unknown field of Lithuanian philosophy?

The most noteworthy aspect of Loyalty, Dissent, and Betrayal is the detailed and pensive description of the types of liberal nationalism propagated by Kavolis, Shtromas, and Venclova. Kavolis's philosophy is West-oriented, cosmopolitan, postmodern (64-67). He sees no point in "fiercely attacking, demonizing, or otherwise discrediting nationalism, which is just another term for the cultural modernization of Central and Eastern Europe" (65). Instead, he advocates modernization of nationalism "by opening up its liberal and inclusive traits" (65) and proposes a new type 
Agata A. Lisiak,

"Review of Books by Donskis, Foster and Wigmore, and Koczanowicz and Singer"

of nationalism, which he calls "postmodern" or "liberal." Kavoli juxtaposes conservative nationalism with liberal nationalism and notes that the latter "allows more room for cosmopolitan stances and multiculturalism in politics in public discourse, as well as the modernizing critique of politics and culture it employs" (68-69). Openness lies at the basis of "a Miłosz-like commitment to one's own nation permeated with a responsiveness to others, a sense of multiple, communicating identities" (Kavolis qtd. in Donskis 69). Interestingly, although not surprisingly, Shtromas also refers to and identifies with Czesław Miłosz in his ideas on (post)Soviet identity. Donskis draws parallels between the Lithuanian philosopher and the Polish author and claims that "Miłosz and Shtromas succeeded where Orwell failed. While Orwell was at his best penetrating the reason and conscience of a separate and isolated individual who was desperately trying to maintain his ability to make logical and ethical distinctions ...Central and East European critics of totalitarianism placed much more emphasis on the collective memory and on the crucial importance of the community of memory and participation" (79). Although the above passage does not specify whether Miłosz and Shtromas mean national, regional, or Central European/(post)Soviet identity, it is clear that both thinkers acknowledge the existence of group identity and its crucial role in resisting totalitarian brainwashing. The question that remains unanswered here is how this common identity equips us in fight against postcolonial abnormalities. Donskis reads most ideas on identity expressed by Miłosz, Shtromas, and Kavolis as commandments of liberal and/or postmodernist nationalism -not unjustifiably so. However, the inclusion of other aspects of identity building developed by the discussed thinkers would add depth to Donskis's study.

The most complex and comprehensive portrait Donskis presents is that of Tomas Venclova, probably the best known Lithuanian intellectual and major representative of Central and East European emigrés. As a patriot criticizing conservative nationalism and as an international humanist scorning communism, Venclova advocates a return from extreme and pathological mutations of both nationalism and cosmopolitanism to their more balanced forms such as liberal nationalism and ethical universalism. Venclova also remains attentive to other social and cultural issues: "Prejudice, superstition, traditional fear of modernity, anti-Semitism, xenophobia, self-centeredness, and self-righteousness are keywords to define the object of his criticism targeted at Lithuanian society and culture" (47). Donskis regards Venclova the conscience and moral advocate of newly independent Lithuania and regrets that the friend of Miłosz and Brodsky receives more recognition in Poland and Russia than in the land of his birth. One of the reasons Venclova is disregarded by so many of his compatriots is his internationalism, which in Lithuania is still associated with Soviet propaganda and a threat to Lithuanian national identity. Furthermore, Venclova explores and brings to light the sensitive and still unresolved issues of Lithuanian-Polish, Lithuanian-Russian, and Lithuanian-Jewish relations. Through his preoccupation with cases of Lithuanian xenophobia and anti-Semitism, Venclova not only discloses complexes and fears tormenting remarkably large parts of Lithuanian society, but also points at the necessity of reconsideration and/or redefining of national identity.

Venclova's liberal approach to the problem of the nation may be (and is) considered by Lithuanian hardliners treacherous. Donskis observes that the concepts of loyalty, dissent, and betrayal -which form the core title of his book -- differ depending on the type of nationalism: "For conservative or radical nationalists, even social and cultural critique of one's people and state can be regarded as nothing more and nothing less than treason, whilst for their liberal counterparts it is precisely what constitutes political awareness, civic virtue, and a conscious dedication to the people, culture, and state" (73). Clearly, according to the above definition, the three Lithuanian thinkers portrayed here are liberal nationalists. However, outside Donskis's book, they are more likely to be considered simply patriots. To explain the difference between patriotism and nationalism, Donskis once again turns to Bauman to whom "nationalism is nothing else than disliked patriotism, whereas patriotism is a well-liked nationalism" (100). Despite the anecdotal nature of Bauman's statement, the differentiation between nationalism and patriotism is a serious and important question that became especially significant in Central and East Europe after the collapse of the Soviet Union. Whereas conservative nationalism looms attractive to workers, clerks, and pensioners, who feel disappointed with the outcome of the democratic transformations, the most ardent supporters 
Agata A. Lisiak,

"Review of Books by Donskis, Foster and Wigmore, and Koczanowicz and Singer"

of moderate patriotism and liberalism can be found at the philosophy departments of Central and East European universities and on executive boards of private business enterprises (see, e.g., Koczanowicz and Singer).

The collection of conference papers compiled by Leszek Koczanowicz and Beth J. Singer propagates US-American-style liberalism as the only solution for post-1989 Poland. Democracy and the Post-Totalitarian Experience is unusually consistent for a conference publication in that all the contributors are unanimous in their praise of economic and social liberalism. The topics discussed at the conference give titles to sections of Koczanowicz and Singer's publication: Democracy and National Identity; Religion, Moral Values, and the Overthrow of Totalitarianism; Liberalism and Democracy; Democracy and Public Reason; Participatory Democracy and Social Justice; The Electronic Media and Democracy; Procedural Transformation; and American Philosophical Conceptions: Implications for Democratization. As we can see, the participants of the conference -- Polish and US-American professors of philosophy -- tackle a wide range of issues, and always from a philosophical perspective and with a clear distinction between liberalism/individualism and communitarianism in mind. The lack of communitarian sympathies the papers of the contributors suggest may be explained in a number of ways. First, most Polish scholars remain disillusioned with the type of Marxism that (mis)shaped the official ideology before 1989 and are distrustful to any philosophy that is somehow related to Marxism. Secondly, rather than confronting such thinkers as Noam Chomsky or Marshall Berman, the organizers of the conference chose to invite those US-American academics who clearly position themselves on the side of conservative liberalism. Furthermore, the conference took place in 1998, which most likely means that the papers had been prepared in 1997, if not earlier. Back then, in the midst of democratic transformations in Central and East Europe, there existed much more resentment for communitarian ideals still reminiscent of the Communist regime. Also, there was more faith in the US-American type of liberalism and capitalism. Possibly, if the same conference were organized in 2005 , when the volume in fact was published, the work presented would be less one-sided.

Nonetheless, Democracy and the Post-Totalitarian Experience is a remarkable, well-structured publication that "confront[s] different aspects of the principles of democracy" (xiv) and considers their implications for Poland. The conference participants discuss the impact of the system change on Polish mentality, social behavior, the justice system, and the media. After more than forty years of the Soviet rule, Poland has to redefine itself both as a state and a nation. Koczanowicz reminds us that the Polish "struggle for preserving national identity" began with the partition of the state at the end of the eighteenth century: "Romantic poetry created symbols, metaphors, and tropes ready for description of the fate of the nation," which became "a means of communication within and between generations in the nineteenth and twentieth centuries" (7). Soviet supremacy was thus perceived as a "continuation of traditional Russian politics of subordination of Poland" (7). Romantic symbols used by the nineteenth-century freedom fighters were taken up by Solidarity in the 1980s and, according to Koczanowicz, "turned out to be crucial for defeating the Communist ideology" (7). Unlike workers' protests in the West, the Polish workers' movement was right-wing and its strength lay in nationalist and deeply Roman Catholic in symbolic and rhetoric: "Public high masses, collective prayers, singing church songs and the national anthem became an indispensable part of every demonstration in 1980-1981 and after Martial Law" (7). At that point, the traditionally close relation between the Polish nation and Roman Catholicism became even tighter -- partly owing to the election of Karol Wojtyla in 1978 as the first Polish pope -- and owing to public opinion, Roman Catholicism became an indispensable pillar of Polish patriotism. Whereas under the Communist regime the exploitation of the close link between nation and religion helped the resistance movement in their fight against the system, after 1989 the growing impact of the church on state politics brought Poland dangerously close to being turned into a theocratic state.

In Democracy and the Post-Totalitarian Experience the impact of Roman Catholicism on Polish national identity is discussed at length, predominantly by Polish scholars (Koczanowicz, Aleksandrowicz, Turowski). Dariusz Aleksandrowicz perceives Roman Catholicism not only as a crucial element of defining Polishness, but also as one of the three main factors -- next to "powerful trade unions" and the "peasantry" (23) -- behind the costs of non-economic transformation in 
Agata A. Lisiak,

"Review of Books by Donskis, Foster and Wigmore, and Koczanowicz and Singer"

post-Communist Poland. Significantly, Aleksandrowicz speaks of Roman Catholicism and not the Roman Catholic Church: "The latter refers to a formal institution. Through its representatives it can be a partner in political bargaining with institutions of political life and of the state. In contrast, 'Catholicism' means a 'culture,' that is, a set of patterns of behavior and of thought" (23). Furthermore, the author makes a clear distinction between moderate (yet still sincere) Catholicism and "popular Catholicism" (25) associated predominantly with the influential Catholic radio station (Radio Maryja) and its charismatic director, Father Tadeusz Rydzyk. Aleksandrowicz draws similarities between Catholic populism and the "working-class culture of state-socialism" (25): both are ideological movements directed at the parts of society disappointed with the outcomes of the system change, both use populist rhetoric, both find their strength in identification of the enemy, "both affirm a model of society in which competition would be limited by some type of ideological regulation and control. Fundamental differences arise with respect to the ideology by which society is to be controlled" (30). Sadly enough, populist movements have been gaining on importance in all of Central and East Europe since 1989, reaching its peak in 2006 when extremist right-wing parties entered local (former East Germany) and state governments (Poland, Slovakia) (on this, see, e.g., Judt; Chiantera-Stutte and Petö). To Polish Roman Catholic hardliners, there is "a close relation between what is pious and what 'Polish'" (34). In other words, representatives of other religions and cultures (especially Jews), agnostics, and atheists are considered "un-Polish" and, as such, unworthy being allowed into the government and the media. Populist Roman Catholics repeatedly "disguise" certain politicians and journalists as "Jews," "free masons," and "traitors" (on this, re Hungary where we find a similar situation, see Marsovszky). Thus, Father Rydzyk and the radio stations Radio Maryja do find listeners and supporters who of course also happen to be voters and have their say in shaping Polish politics. To Mariusz Turowski, however, the political impact of Roman Catholicism seems exaggerated: "Polish Catholicism is much more connected to Polish nationality than to political attitude" (47). Aleksandrowicz adds that "in the Polish cultural tradition nationalism and (Catholic) religion became strongly connected as early as the seventeenth century" (34) and that "the idea of the 'Mother of God as the Queen of Poland'" (35) is still tremendously popular in Polish society. Again, we need to keep in mind that both authors make their judgments on the basis of political developments of the 1990 s when populist Roman Catholicism in Poland was remarkably strong, but not as politically influential as it became during and after the 2005 parliamentary and presidential elections.

Concluding his deliberation on religion and politics in Poland, Turowski wonders "whether Poland should try to overcome this 'Polish specialty' ... or should we accept our situation as the 'Polish peripheral spirit' and examine the possibility of moving forward to fulfill 'Polish peripheral political expectations" (47; on the "in-between peripheral" locus of Central and East European cultures, see Tötösy de Zepetnek). The US-American participants of the conference give a clear answer to Turowski's question: Poland should adopt the US-American model. In the last section of the book Richard P. Mullin, Sandra B. Rosenthal and Rogene A. Buchholz, and Judith M. Green elaborate on the advantages of US-American idealist and pragmatist philosophies and the positive effects their application should bring to post-Communist Poland. Mullin seeks the basis for democracy in Josiah Royce's idea of loyalty: "Because loyalty is a necessary condition for both individuality and community, it is a prerequisite for any other good" (184). It is true that "democracy cannot survive without a substantial portion of citizens who are loyal to democratic values" (184), however, Mullin seems to forget that Polish society cannot be spontaneously loyal to democratic values for the simple reason that it is unfamiliar with them. Poland and other Central and East European countries have to take lessons in democracy and understand its workings before they can become faithful to it. According to Rosenthal and Buchholz, "American democratic theory is the natural place to look for a solution" (193) to national and ethnic conflicts that gained on fierceness and momentum in Central and East Europe after 1989. The region has always been culturally varied, but its diversity was suppressed under the Communist rule: pluralism was replaced by "a factitious sense of direct union and communal solidarity" (Dewey qtd. in Rosenthal and Buchholz 193). After the system collapsed, ethnic and religious minorities became visible again and started calling for their rights, which led to numerous -- sometimes brutal -- misunderstandings and conflicts. Rosenthal 
Agata A. Lisiak,

"Review of Books by Donskis, Foster and Wigmore, and Koczanowicz and Singer"

and Buchholz claim that John Dewey's "pragmatic understanding of community [which] does not negate, but requires, individuality, freedom, and pluralism" (200), is the only realistic solution for post-totalitarian and culturally diverse democracies. Similarly, Green advocates Dewey's radical pragmatic approach to democratization as promising for young Central and East European democracies and, furthermore, proposes to apply Dewey's philosophy in economics. Green's article is the gem of the volume not only owing to its clarity and good argumentation, but because it tackles the issue of economy, largely overlooked by other authors despite its crucial role in the posttotalitarian experience of Poland, as well as in other countries of the region. In contrast to the painful market reforms designed by Sachs and Balcerowicz, Green suggests the use of a more humane alternative: "Deweyan radical pragmatism could guide preferable, actively participatory processes of democratization that would be inclusive of those now-oppositional voices that helped to achieve the 1989 revolution. In combination with nationally and internationally supported but locally and regionally focused democratic participatory processes of economic revitalization, schools and universities could nurture those processes of moral-intellectual development that allow people to become both appreciative and critical community members while cultivating the knowledge and skills they will need for a deeply democratic way of life" (216). Public participation in the transformation processes is not only pivotal to the deepening and cultivation of democracy, but also decisive for development of national and local identities. Presumably, if the inhabitants of Karpacz (the mountainous whereabouts of the conference) were invited to partake in decision-making processes regarding local investments (and made use of the invitation), they would be more willing to contribute time and work to local developments, more likely to identify with the community, and less inclined to perceiving foreign investors (especially those from nearby Germany) as mere colonizers.

Complicated and highly emotive relations between neighboring states and nations have had an enormous impact on the democratic transformations of the region and some of the conflicts that marked international and domestic politics in the region are century-long and so deeply embedded in the common consciousness that they appear to be natural part of national and/or regional mentality. The contributors to the volume Neighbors and Strangers discuss complex cultural relations in Central Europe after 1989. The editors of the volume take a closer look at how contemporary literature responds to the transformation processes that shape the region. The papers collected by Foster and Wigmore's (and first presented at a conference at the University of Salford in 2002) focus on German and/or German-speaking literature. The most striking feature of all discussed works is their preoccupation -- if not obsession -- with the past. Memories, monuments, memorials, and museums create the basis and background for contemporary novels and plays. Historical relations between Germany and its eastern neighbors gained on importance after the fall of the Berlin Wall and German reunification and found their way into literature. Interestingly, whereas Donskis perceives writers as prophets who grasp political tendencies better than professional analysts (119), it seems that the authors discussed in Neighbors and Strangers hardly ever dare look into the future: they prefer to muse over the past in an attempt to unravel the secrets of their own identities. Unlike Democracy and the Post-Totalitarian Experience, the conference papers edited by Foster and Wigmore are not divided into sections. Nevertheless, the book is thematically consistent, possibly because all articles deal with the same topics: identity, the totalitarian past, and the concept of Heimat (homeland). After 1989, the hitherto hidden or neglected traumas came to surface and were readily picked up by writers. Several contributors to the volume focus entirely on the fate of Central European Jews and discuss it together with national guilt and geographic and cultural displacement. In post-1989 German(-speaking) literature, Jews are portrayed either as discriminated inhabitants of Central European shtet/s and cities (Preece), or as their descendants revisiting the ancestral land (Bushell, Wigmore). Central Europe, especially its easternmost part, Galicia, provides a multiethnic setting for Edgar Hilsenrath's Jossel Wassermanns Heimkehr (1993). Unlike in some contemporary Ukrainian (Andruchowycz) and Polish (Stasiuk) fiction and feuilleton writing, however, Hilsenrath's Galicia is hardly a multicultural idyll. The author considers anti-Semitism "a universal east European phenomenon" (29) and tries to explain its origins: "the Jews were Emperor Franz Joseph's most loyal subjects, just as they had loyally served the Polish 
Agata A. Lisiak

"Review of Books by Donskis, Foster and Wigmore, and Koczanowicz and Singer"

kings and landowners in the late Middle Ages. While all the other peoples wanted their own state (and the Czechs deserted en masse to the Russians in the World War), the Emperor could trust his Jew. They had no one else protect them" (29). The complex identity of Central European Jews and their social ostracism is also discussed in Günter Grass's Im Krebsgang (2002). However, rather than pointing the finger at the brutality of anti-Semitism, the author chooses to let the Central European strike back. Grass's character David Frankfurter (inspired by and bearing the name of a real-life person), a multilingual Serbian Jew, kills the famous Nazi leader, Wilhelm Gustloff and, hence, takes a symbolic revenge on Germany. As a single event, this assassination might have been forgotten, if not for the German cruise ship named after Gustloff, which the Soviets torpedoed in 1945 and let it sink with thousands of German women and children on board. Grass implies that Frankfurter's vengeful quest becomes completed only then, with the tragic mass death of German civilians. Grass's account of dreadful historical events sheds a bright light on the painfully interwoven fates of Central and East European nations.

Whereas new German novels dealing with the issue of Central Europeanness remain largely preoccupied with prewar and war calamities, contemporary Austrian prose approaches the problematic past through a mediator. Bushnell and Wigmore claim in their articles that the motif of a returning Jew helps Austrians come to terms with postwar Austrian identity. Anna Mitgutsch's Haus der Kindheit (Bushnell) and Elisabeth Reichart's Nachtmär (Wigmore) examine national guilt about the Nazi past as experienced by the postwar generation. Bushnell describes this trend with catchy phrases: "the Return of the Native" and "the Neighbours are back" (85) and interprets Mitgutsch's novel as "a somber and sober investigation of communal relationships" (101). Meaningfully although not unexpectedly, Mitgusch's protagonist is a US-American Jew of Austrian origin. Therefore, Austrian society is confronted not only with returning Jews who provoke confrontations with the country's infamous past, but also with the influx of US-American beliefs and values that became especially influential in Central Europe after 1989. Similarly, a US-American ancestor of Austrian Jews named Esther plays a crucial role in Reichart's novel. The US-American aspect of the "Return of the Native" adds another dimension to historical revisions as "the presence of America fulfills the role of a utopian safety value" (101).

In the volume, next to the Nazi past, Communism is another totalitarian experience discussed at length by German(-speaking) authors. In her paper on Irene Böhme's Die Buchhändlerin (1999), Renate Rechtien voices a loud protest against the trivialization of Germany's National Socialist past and the attempts "to place the lion's share of the responsibility for it firmly at the door of East German citizens" (219). Rechtien accuses Böhme for presenting a distorted and unfair portrait of East Germany (GDR) "as a continuation of National Socialism under totalitarian communist rule" (233): "Irene Böhme's novel affirms dominant conservative thinking that it is no longer the National Socialist past that needs to be critically examined by all Germans, or West Germany's recent past that needs to be subjected to critical scrutiny by West Germans, but rather that it is exclusively East German history which now needs to be 'overcome' in order for Germany, finally, to achieve 'normality'" (234). Whereas Rechtien's frustration at the unequal treatment of both German societies (and identities!) is understandable, the author prefers to overlook a crucial fact: West Germany made more effort to examine its Nazi past (first in 1968, then in the 1980s) than the GDR. For decades, the East German communist government either ignored the issue altogether or claimed that the Nazis were only in West Germany -- hence the official name of the Berlin Wall: Anti-Fascist Protective Rampart (antifaschistischer Schutzwall). Perhaps, then, Böhme is not altogether unfair in pointing out the strikingly different practices of dealing with the Nazi period of German history.

Irena Brežna's collection of articles Falsche Mythen. Reportagen aus Mittel- und Osteuropa nach der Wende (1996) also deals with the totalitarian past. As a Slovakian emigrée, Brežna observes her home country from a perspective of both a native and an outsider. After twenty years of forced absence, the author tries to rediscover the country of her birth and happens to do so at one of the most turbulent moments in its history: the revolution of 1989 . Koštalova interprets Brežna's texts as an endeavor at objectification and rectification of the image of Central and East Europe after a long absence (75). Brežna has to confront anew not only her identity as a Slovak 
Agata A. Lisiak

"Review of Books by Donskis, Foster and Wigmore, and Koczanowicz and Singer"

and/or Czechoslovak, but also as Central European. As in other works of contemporary German(speaking) literature, also here coming to terms with the uncomfortable past and the uncertain and rapidly changing present affects the process of (re)building national identity and the understanding of home. The search for Heimat is one of the main themes in new prose written by Romanian Germans and strikes as especially captivating in Richard Wagner's fiction and feuilleton writing. Born as a member of the German community in Romania, Wagner "sees himself as a German writer with a strong sense of his German identity" (Rock 55). Nevertheless, after he moves from provincial Banat to cosmopolitan Berlin, his Germanness loses on strength and gives room to Central Europeanness (Rock 66). In his superb analysis of Wagner's writing, David Rock notices that the author seems to adapt Berlin as his new home; however, Wagner objects and claims that feeling at home (zu Hause) is not exactly the phrase to describe his state of mind. If to Wagner Berlin looms as the most attractive German city, it is because of its Central European nature. Even if he still considers himself a German writer, Wagner's Germany is "a cultural concept -- the culture nation. ... And as far as Romania is concerned, Romania has always been a state to me. What I developed a relationship with was the Banat, the region. In Central and East Europe the regions are more important than the states, they are also older. For minorities, it is obvious to identify foremost with the region" (Wagner qtd. in Rock 67; unless indicated otherwise all translations are mine). Rock adds that Wagner's views on national and regional loyalties explain "his choice of Berlin as place of residence, precisely because it is not a quintessentially German city, but rather a cosmopolitan meeting point between East and West, and so it represents for him the nearest thing to a cultural home" (67-68). We need to keep in mind, however, that Berlin regained its Central Europeanness only after the fall of Communism, when it won back its ideological freedom and became a chosen home (Wahlheimat) (chosen homeland) to miscellaneous national, ethnic, and religious groups. Multicultural again, Berlin re-entered the fractured tradition of ethnically diverse cities. Similar trends can be also slowly observed in other Central and East European metropolis such as Prague, Budapest, Krakow, and Vilnius. What future awaits these cities and the part of Europe they belong to?

After reading Koczanowicz's and Singer's Democracy and the Post-Totalitarian Experience, Foster's and Wigmore's Neighbours and Strangers: Literary and Cultural Relations in Germany, Austria and Central Europe since 1989, and Donskis's Loyalty, Dissent, and Betrayal: Modern Lithuania and East-Central European Moral Imagination, the following conclusion comes to mind: to an idealist, the present situation means a recovery of the multicultural Central European "paradise," a pessimist would claim that Central European ethnic diversity has always been a nightmare rather than a dream, and a realist would most likely look for answers by the new administrator of the region: the European Union.

\section{Works cited:}

Chiantera-Stutte, Patricia, and Andrea Pető. "Cultures of Populism and the Political Right in Central Europe." CLCWeb: Comparative Literature and $\quad$ Culture $5.4 \quad$ (2003): <http://docs.lib.purdue.edu/clcweb/vol5/iss4/2>.

Bauman, Zygmunt. "Preface." Loyalty, Dissent, and Betrayal: Modern Lithuania and East-Central European Moral Imagination. By Leonidas Donskis. Amsterdam: Rodopi, 2005. ix-xii.

Donskis, Leonidas. Loyalty, Dissent, and Betrayal: Modern Lithuania and East-Central European Moral Imagination. Amsterdam: Rodopi, 2005.

Foster, Ian, and Juliet Wigmore, eds. Neighbours and Strangers: Literary and Cultural Relations in Germany, Austria and Central Europe since 1989. Amsterdam: Rodopi, 2004.

Judt, Tony. "The 'Problem of Evil' in Postwar Europe." The New York Review of Books (14 February 2008): 3335.

Koczanowicz, Leszek, and Beth J. Singer, eds. Democracy and the Post-Totalitarian Experience. Amsterdam: Rodopi, 2005.

Marsovszky, Magdalena. "Cultural Essentialism in Post-1989 Hungary." The New Central and East European Culture. Ed. Steven Tötösy de Zepetnek, Carmen Andras, and Magdalena Marsovszky. Aachen: Shaker Publisher, 2006. 268-76.

Tötösy de Zepetnek, Steven. "Comparative Cultural Studies and the Study of Central European Culture." Comparative Central European Culture. Ed. Steven Tötösy de Zepetnek. West Lafayette: Purdue UP, 2002. 132. 


\section{Agata A. Lisiak,}

"Review of Books by Donskis, Foster and Wigmore, and Koczanowicz and Singer"

page 10 of 10

CLCWeb: Comparative Literature and Culture 9.4 (2007): <http://docs.lib.purdue.edu/clcweb/vol9/iss4/6>

Reviewer's profile: Agata Lisiak is working towards her doctorate in media, culture, and communication studies at the University of Halle-Wittenberg, with a dissertation entitled Communication and Urban Identities in Post1989 Central Europe. In addition to numerous publications in Polish and translations from Polish to English, Lisiak's English-language publications include "Central and East European Culture(s) and Slavic Literatures and Cultures" in The Horizons of Contemporary Literary Comparative Studies in Slavonic Countries. Ed. Halina Janaszek-Ivaničková (2007) and the book review article "Memories of Communism in Central and East Europe: New Work by Janaszek-Ivaničková, Modrzejewski and Sznajderman, Rév, and Spiewak" in CLCWeb: Comparative Literature and Culture 6.2 (2004). E-mail: <clcweb6@purdue.edu> 